\title{
Promoting Mindfulness about the Environment through the Use of Drama in the Primary Classroom: Greek Teachers' Views and Attitudes
}

\author{
Evanthia Andrikopoulou and Konstantina Koutrouba * \\ Department of Home Economics and Ecology, Harokopio University, 17671 Athens, Greece; eandrikop@hua.gr \\ * Correspondence: kkout@hua.gr
}

Received: 2 December 2018; Accepted: 21 January 2019; Published: 23 January 2019

\begin{abstract}
The present questionnaire-based study examines Greek teachers' views and attitudes towards drama-based activities in primary education classrooms when conducting Environmental Education programs. More specifically, 330 teachers provided information about (i) how the development of drama-based activities in the classroom facilitates the effective attainment of Environmental Education objectives, (ii) the expected cognitive and socio-affective benefits for the students, and (iii) their suggestions for improvements when they assess the students' professional performance during drama-based activities. The results of the study show that, when Environmental Education is based on drama activities, it has a significant impact on students. Teachers believe that it increases resourcefulness, generates deeper understanding, empathy, willingness to participate in social actions, sharing responsibility and commitment, as well as sensitivity. However, the research shows that teachers need to be well trained, sufficiently motivated, inspired, and supported if drama-based activities in Environmental Education are expected to have the abovementioned impact.
\end{abstract}

Keywords: drama; environmental education; primary education; Greek teachers

\section{Introduction}

Various forms of art, such as music, drama, and fine arts, have been used as a teaching method in education during the last few decades. They are used as educational tools by teachers not only for theoretical subjects, like languages, history, poetry, etc. [1-4], but also for more practical lessons such as technology, mathematics, psychology, biology and health sciences, physics, chemistry, geography, etc. [5-9]. As far as students are concerned, research has revealed that their engagement in arts within the classroom triggers their interest in learning, increases their self-esteem, and enhances their ability to manage difficult situations to better understand and assimilate difficult concepts [5]. As students exercise their imaginative skills, they discover new possibilities for themselves and for others [5]. With regard to the teachers, according to the Brazilian educator Paulo Freire, the arts enable them to transform their role, "democratize" the classroom and, in general, enhance freedom and create a positive learning environment in the classroom [10-12]. A positive learning environment can more easily generate interest and enthusiasm for the lesson [13]. All arts-drama and its various activities-such as dramatic play, improvisations, dramatization, role-play, pantomime, etc., have been proven to create an effective learning and educational environment $[5,13]$. The use of drama-based activities as a teaching strategy manages to involve each student in a unique atmosphere, where he/she can share his/her own thoughts and ideas [14]. The use of drama-based activities strengthens the interaction between teacher and student, in which the "transfer of power" from the adult (i.e., teacher) to the child (i.e., student) is achieved [15]. The teacher ceases to function as an "authority" but seeks learning and new ways of understanding along with her/his students [16]. There are two equally 
important stages when using drama-based activities in the educational process: the first stage is the "in role" process in which-together-the teacher and the student act, react, and shape their perceptions of the world and people; the second step is the "out of the role" evaluation in which they analyze and reflect in order to understand human reactions and actions [13]. The use of drama-based activities in the educational process offers-more than other activities in school—opportunities for effective experiential intercultural learning, because through the experience of interacting with her/his classmates the student develops active listening, empathy, acceptance of and respect for the others, and also social skills and a critical attitude towards life [17]. It is a great challenge for primary school teachers to contribute to the emotional and aesthetic development of students, working in a framework of standardization and uniformity in the teaching methodology [18]. It is also the responsibility of university departments and the state to train primary school teachers in appropriate pedagogical methods that will revitalize their teaching [19].

In the official Greek educational Curricula for Elementary School, drama lessons (called in Greek theatriki agogi) were introduced in 1990 (Presidential Decree No132/10-4-1990), and taught to all six classes of elementary school by drama teachers, aiming to encourage students (age 6-11) to develop skills and inclinations that enable them to function harmoniously both as individuals and as team members. Students learn basic drama activities through dramatic play (i.e., a child-oriented activity that includes: imitative role play, make-believe with regard to objects, make-believe in regard to actions and situations, interpersonal interaction, verbal and non-verbal communication and narratives) $[4,20,21]$.

\subsection{Environmental Education and Drama-Based Activities}

Environmental Education focuses on environmental and social problems, and is considered to be fundamental if a society wishes to inculcate the citizen of tomorrow with a sense of environmental responsibility, environmental ethics, and ecological consciousness [22,23].

Despite apparent concerns worldwide about severe global environmental issues, active steps towards radically addressing the problems by world leaders and societies remain quite reluctant and hesitant. In other words, a huge gap exists between knowledge and action that has to be effectively bridged as soon as possible. To reduce the gap between knowledge and action, there is no need for more information, but a different way of communicating this information [24]. Therefore, in order to change our attitude towards the environment for the better, we need to explore alternative forms of environmental education, as knowledge alone is not enough to induce a change in behavior [25].

There is a growing awareness that the arts play an important role and have a decisive impact on beliefs and attitudes towards the environment [26]. Curtis and colleagues [27] reported that arts in environmental or science education can increase student interest and improve their ability to make connections between environmental crises and cultural impact [28], motivate children to express themselves, engage them on a personal level about ecological concerns [29], and encourage pluralistic and evaluative thinking [30].

Drama in particular can sensitize students regarding relationships between humans and nature [31], and help them not only express their perceptions, opinions, and attitudes, but also revise them [17]. Drama-based activities can provide students with the basic principles of the ecosystem, and help them build new knowledge through their experiences [14]. Moreover, through drama-based activities, it is possible for the students to understand specialized scientific terms, methods, and techniques, which contribute to addressing environmental issues [32].

According to the literature, international surveys with primary school students have concluded that drama in education contributes significantly to raising students' interest in participation and action in relation to the environment and the world around them. More specifically, a survey by Çokadar and Yilmaz [14] showed that drama-based activities can provide students with the basic ecosystem principles through which they will build new knowledge through their experiences. McNaughton [13], examined the use of educational drama in the teaching of Sustainable Development Education in the last grades of elementary school, and demonstrated that students develop those skills and behaviors 
that are necessary for a future active citizen, also in addition to empathy and compassion. Another survey by Bailey and Watson [33] about the potential benefits of using drama-based activities and role-play with students aged 7-11, who were expected to understand basic ecological concepts, showed a clear difference in the level of understanding between the students who used drama-based activities and role-play and those who did not. Their survey also reported that when the emotional field of teaching objectives is reinforced during the teaching and learning process, students will be able to be part of the global community and not simply spectators.

Through drama, it is possible to understand specialized scientific terms, methods, and techniques, which contribute to solving environmental issues and problems [32]. As shown in the survey by Curtis and colleagues [27], drama-based activities not only lead to the improvement of environmental knowledge and perceptions of students, but also constitute a tool for synthesizing and presenting scientific research in creative and multi-level ways that stimulate students and ultimately help them sustain their attention and commitment to knowledge. Clark and Button [34], in their survey presented an interdisciplinary educational model (STEM-Sustainability Transdisciplinary Education Model), a modern approach that links art, science, and society, which has been developed to provide university students, primary school students, and societies in general with common opportunities in learning. As a result, all participants gained a deeper and broader understanding of human-environment relationships, they developed their ability to access academic areas of knowledge and creatively address the challenges of sustainability. Littledyke $[35,36]$ in his surveys, came to the conclusion that the use of drama-based activities developed the socio-emotional skills of students and motivated their interest to actively participate in environmental issues.

The introduction of Environmental Education into the official Greek educational Curricula of Elementary Schools took place in 1991 (Greek Government Gazette 223/12-4-1991, B'). The aim of Environmental Education is to make students aware of the relationship between people and their natural and social environments and of the problems associated with it, and to engage them in specific Environmental Education Programs (i.e., programs supported by the Greek Ministry of Education for promoting Environmental Education in elementary and secondary public and private schools) in order to make them contribute to the general effort of raising environmental awareness. Under the same law, the Environmental Education Directors (i.e., official authorities supervising the implementation of Environmental Education in public and private schools) and the Environmental Education Centers (i.e., centers promoting Environmental Education to students' and the educators' community by organizing educational programs and informational seminars) were instituted.

The aim of the present questionnaire-based study research was to explore Greek primary school teachers' perceptions about: (i) the use of drama-based activities as a means of enhancing, supporting, and developing the multi-layered objectives of Environmental Education; (ii) the expected students' cognitive and socio-affective benefits, and behavioral outcomes: and (iii) their self-assessment regarding implementation of drama-based activities in the Environmental Education Programs. The importance of conducting researches on teachers' views and perceptions about educational matters is supported by the TALIS (Teaching And Learning International Survey) research [37].

This research contributes to the international literature by linking environmental awareness with the use of drama-based activities. Although there are a few existing studies with students, both abroad and in Greece-not many indeed-, there is even less research exploring teachers' perceptions about the particular educational method.

\section{Materials and Methods}

The present research that took place in the first semester of the academic year 2017-2018, is the third part of a survey that has been conducted in three stages since 2015 with permission from the Greek Ministry of Education, Research, and Religious Affairs. During the first stage of the study (2015-2016), the researchers examined (through the use of a questionnaire especially designed for the study) how 28 students of Primary Education Schools in Greece (aged 10-11 years) 
experienced measurable changes regarding their knowledge, feelings, and behaviors after they had been familiarized with alternative teaching techniques that included the implementation of drama activities during Environmental Education [38]. The second stage of the survey took place in 2016-2017. Due to the fact that the existing international literature could not provide the researchers with an instrument suitable for the purpose of this survey, they designed and used a new self-administered questionnaire comprising in total of 49 close-ended questions, of which, 35 were followed by nominal five-point Likert-type scales. The questionnaire was based on previous academic and environmental research organizations, which were processed and adapted to Greek conditions. Then, the researchers came in contact - through e-mail and in cooperation with the Principals of the schools-with 400 Primary Education teachers who worked in the capital city of Greece, Athens, asking them to fill in a corresponding number of questionnaires. Of these, 330 returned their questionnaires fully and correctly completed (response rate: $82.5 \%$ ). During the second stage, the researchers elaborated the data of eleven questions of the questionnaire, and presented their findings [39] on how the 330 Greek teachers felt and reacted when they were asked to use drama-based activities in order to promote the principles of Environmental Education in their Primary School classrooms.

During the present third stage, the researchers elaborated the data drawn from the 38 remaining questions of the questionnaire used in the second step of the research and, taking into account the findings of the previous steps, recorded and analyzed (through fifteen questions) the overall attitudes of teachers towards drama-based education not only regarding Environmental Education, but also regarding all educational activities in the classroom. Moreover, in the third step of the survey, researchers examined (through seven questions) how teachers evaluate their own performance during the development of eco-theatre activities within the classrooms they teach in. Finally, sixteen questions were used to draw information about the personal academic and professional profile of the teachers in order for the researchers to examine how this profile had an impact on their attitudes towards, and beliefs about, drama-based activities that are implemented in classrooms where Environmental Education objectives are expected to be attained.

The data of the questionnaires were elaborated and statistically analyzed with a Statistical Package for Social Sciences (SPSS) 22.0 (SPSS, Chicago, IL, USA), while factor analysis with varimax rotation was used to detect the factors that affect teachers' attitudes and beliefs regarding drama-based activities during the educational process. Based on the Principal Component (Rotation Method: varimax), the 33 variables were grouped into four factors. The first factor accounted for $32.9 \%$ of the volatility, and the second for $29.2 \%$. In total, the 2 factors with eigenvalue $>1$ accounted for $62.1 \%$ of the variability. Loads ranged from 0.42 to 0.85 . The third factor explained $57.8 \%$ of the volatility. Loads ranged from 0.71 to 0.82. The fourth factor explained $40.2 \%$ of the volatility. Loads ranged from 0.55 to 0.75 .

Subsequently, the individual questions of each factor were summed up, and their sum divided by their number. To ensure the internal reliability of the questionnaires, Cronbach's-a coefficient was used. Significance levels were twofold, and the statistical significance was set to 0.05 . The values in the first factor ranged from 1.17 to 5.00 points, with an average of 4.22 points ( $S D=0.63$ points). Values in the second factor ranged from 2 to 5.00 points, with the average value being 4.39 points ( $S D=0.54$ points). The scores in the ratings for the third factor ranged from 1 to 5 points, with an average value of 4.31 points ( $\mathrm{SD}=0.56$ points). The values in fourth factor ranged from 1.43 to 5 points, with an average value of 3.73 points ( $\mathrm{SD}=0,6$ points). Cronbach's confidence factors were above the acceptable limit (0.7), so the questionnaire's reliability was acceptable.

\subsection{Participants' Profile}

The profile of the respondents with regard to gender, age, years of teaching experience, participation in further education programs, postgraduate qualifications, and general attitude towards drama-based activities in the classroom can be seen in Table 1. 
Table 1. Participants' profile.

\begin{tabular}{lcc}
\hline & Participants' Profile & $\%$ \\
\hline 1. & Gender & \\
& Women & 78 \\
Men & 22 \\
\hline 2. & Age & \\
25-35years & 17.5 \\
36-45 years & 38.8 \\
Over 46 years & 43.7 \\
\hline Teaching experience & \\
0-5 years & 4.5 \\
6-15 years & 38.8 \\
16-25 years & 36.1 \\
Over 26 years & 20.6 \\
\hline Post graduate qualifications in Educational Sciences & 36.7 \\
Master Degree & 4.5 \\
PhD & 58.8 \\
\hline None & \\
\hline Type of programs/seminars attended on the use of drama-based & \\
activities in the classroom & 75.4 \\
Seminars by the directors of environmental education & 32.2 \\
Seminars organized by universities & 6.4 \\
Erasmus programs & 40.7 \\
Training programs organized by environmental education centres & 29.5 \\
Training programs organized by Environmental organizations & 29.5 \\
Conferences & 7.9 \\
None & 1.2 \\
\hline Other & \\
the classroom & 19.6 \\
\hline Sot at all important & 5.0 \\
Moderately important & \\
Very important & \\
Extremely important & \\
\hline
\end{tabular}

\section{Results}

\subsection{Special Questions}

Variables 1-15 of Table 2 present teachers' responses to questions regarding their views about the use of drama-based activities in the educational process in general.

As far as the teachers' views on the educational objectives of the Primary Education set by the Ministry of Education were concerned, $88.2 \%$ agreed that the use of drama-based activities in the educational process in general promoted the development of positive attitudes towards lifelong learning, co-operation, and responsibility, while $84.8 \%$ agreed that the construction, comprehension, and deep understanding of basic concepts and principles were being promoted.

Teachers linked strengthening the cognitive domain of teaching objectives with the use of drama-based activities in the educational process in general, with agreement rates ranging from $73 \%$ to $91.8 \%$. Teachers considered the use of drama-based activities in the classroom to be a strong incentive for engaging students in the learning process (91.8\%), and improving the students' language levels $(88.1 \%)$. At the same time, the majority of participants agreed that learning potential through student research activities $(78.8 \%)$, and the academic profile of the students $(73 \%)$ were consolidated.

Moreover, participants considered that the use of drama-based activities in the educational process generates empathy $(89.1 \%)$, increases students' emotional intelligence (92\%), and readiness in 
accepting diversity (89.1\%), while they also believed that it helps students create a safe environment for expressing their feelings $(86.4 \%)$, a condition required for effective teaching.

The majority of the participants reported that through the use of drama-based activities in the classroom, teachers can promote collaborative learning (95.2\%) as well as enhance interaction between students $(97.2 \%)$, and between students and teachers $(94.5 \%)$.

Finally, teachers were able to more easily eliminate any offensive behaviors $(71.2 \%)$ and enhance their students' ability to concentrate and focus (77.9\%) through the use of drama-based activities in the classroom.

Variables 16-26 of Table 2 display teachers' answers to questions regarding their personal perceptions about the implementation of drama-based activities that take place during the teaching of environmental issues. According to the majority of the respondents, these activities may help students develop a profound understanding of environmental issues (87.5\%), while it is expected to strengthen their ability to successfully cope with contemporary problems regarding the environment $(86.7 \%)$. Moreover, according to the majority of the respondents, drama-based activities in Environmental Education are expected to increase students' willingness to get involved in actions regarding the protection of the environment $(90.9 \%)$, providing them with motivation and enthusiasm $(88.2 \%)$ and, at the same time, with a feeling of self-responsibility towards the society where they are expected to live in as member-citizens in the future $(82.7 \%)$.

In addition, the majority of the respondents, reported that students who participate in relevant drama-based activities tend to improve their ability for developing a more complicated system of environmental values $(91.2 \%)$, and to describe in a more precise way deeper feelings and thoughts $(91.8 \%)$. Finally, the majority of the participants reported that drama-based activities are expected to facilitate shared responsibilities and effective cooperation during group work in Environmental Education (93.7\%).

Variables 27-32 of the same Table present teachers' responses to questions regarding their self-evaluation for the use of drama-based activities in the context of implementing Environmental Education Programs.

Participants' responses to their self-assessment on the use of drama-based activities in the context of implementing Environmental Education Programs reflected their positive attitude towards the use of drama-based activities and other alternative educational methods on one hand, but also the sense of insufficiency they experienced, due to inadequate training, when they had to experiment with such teaching methods. Thus, only $25.8 \%$ of the participants felt they were well-trained and confident enough to use drama-based activities in the context of Environmental Education Programs, although the majority of participants agreed that the use of drama-based activities can facilitate such Programs' implementation $(81.8 \%)$.

Due to this sense of inadequacy, many of the participants preferred to apply drama-based activities in the context of Environmental Education Programs with the collaboration of colleagues (57.1\%). Another problem that may negatively affect teachers is time pressure, as a large percentage of teachers suggest that there is a need for the official Curricula to be reorganized so that they include more time for the use of drama-based activities in the classroom $(72.2 \%)$.

Finally, teachers pay great attention to the evaluation of their teaching work, and this is reflected in the high agreement rates of the two last variables (32 and 33), which reflect the importance of assessment both by the Environmental Education Directors (71.8\%), and by the students themselves $(73.1 \%)$. 
Table 2. Teachers views regarding the use of drama-based activities in the educational process.

\begin{tabular}{|c|c|c|c|c|c|c|}
\hline \multirow[t]{2}{*}{ Variables } & & $\begin{array}{c}\text { Totally } \\
\text { Disagree }\end{array}$ & $\begin{array}{l}\text { Slightly } \\
\text { Disagree }\end{array}$ & $\begin{array}{c}\text { Neither } \\
\text { Disagree } \\
\text { nor Agree }\end{array}$ & $\begin{array}{l}\text { Slightly } \\
\text { Agree }\end{array}$ & $\begin{array}{l}\text { Totally } \\
\text { Agree }\end{array}$ \\
\hline & & $(\%)$ & $(\%)$ & $(\%)$ & $(\%)$ & $(\%)$ \\
\hline \multicolumn{7}{|c|}{ I believe that through the use of drama-based activities in educational process in general: } \\
\hline 1 & $\begin{array}{l}\text { Basic concepts and principles of elementary education } \\
\text { are promoted }\end{array}$ & 0.9 & 0.5 & 13.8 & 50.5 & 34.3 \\
\hline 2 & $\begin{array}{l}\text { Positive attitudes towards lifelong learning, collaboration } \\
\text { and responsibility are promoted }\end{array}$ & 1.5 & 1.5 & 8.8 & 45.8 & 42.4 \\
\hline 3 & $\begin{array}{l}\text { Motivation to engage students in the learning process is } \\
\text { increased }\end{array}$ & 0.3 & 3 & 4.9 & 33.4 & 58.4 \\
\hline 4 & $\begin{array}{l}\text { The learning potential through students' research activities } \\
\text { is reinforced }\end{array}$ & 0.6 & 3.3 & 17.3 & 45.5 & 33.3 \\
\hline 5 & $\begin{array}{l}\text { Students' academic profile is improved (improving } \\
\text { cognitive level) }\end{array}$ & 1.2 & 4.3 & 21.5 & 42.5 & 30.5 \\
\hline 6 & $\begin{array}{l}\text { Students' language skills are improved (speech } \\
\text { enhancement, vocabulary enrichment etc.) }\end{array}$ & 0 & 1.8 & 10.1 & 34.9 & 53.2 \\
\hline 7 & $\begin{array}{l}\text { The emotional intelligence of the students is promoted } \\
\text { (ability to recognize, accept and express the feelings of } \\
\text { themselves and others) }\end{array}$ & 0 & 1.5 & 6.4 & 27.7 & 64.3 \\
\hline 8 & $\begin{array}{l}\text { A safe environment is created for expressing students' } \\
\text { feelings }\end{array}$ & 0 & 1.2 & 12.4 & 30.3 & 56.1 \\
\hline 9 & $\begin{array}{l}\text { Offending behaviors (including verbal and/or physical } \\
\text { violence) within the classroom are eliminated }\end{array}$ & 1.5 & 3.6 & 23.6 & 40.6 & 30.6 \\
\hline 10 & Students' ability to concentrate and focus is developed & 0 & 3 & 19.1 & 46.7 & 31.2 \\
\hline 11 & Peer tutoring is enhanced & 0 & 0.9 & 3.9 & 35.8 & 59.4 \\
\hline 12 & Interaction between students is encouraged & 0 & 0.6 & 2.1 & 32.7 & 64.5 \\
\hline 13 & Interaction between students and teachers is consolidated & 0 & 0.9 & 4.5 & 33.6 & 60.9 \\
\hline 14 & Acceptance of diversity among students is increased & 0 & 1.5 & 9.4 & 36.1 & 53 \\
\hline 15 & $\begin{array}{l}\text { Enhanced empathy of students (The ability to recognize the } \\
\text { needs of others and to accept each other as they are) }\end{array}$ & 0.3 & 0.6 & 10 & 36.7 & 52.4 \\
\hline \multicolumn{7}{|c|}{ I believe that during drama-based activities in Environmental Education: } \\
\hline 16 & $\begin{array}{l}\text { Students develop a deeper understanding of } \\
\text { environmental issues }\end{array}$ & 0.3 & 0.9 & 11.2 & 53 & 34.5 \\
\hline 17 & $\begin{array}{l}\text { Students develop an ability to successfully cope with } \\
\text { contemporary problems regarding the environment }\end{array}$ & 0.6 & 0.6 & 12.1 & 49.7 & 37 \\
\hline 18 & $\begin{array}{l}\text { Students develop vivid experiences and feelings about the } \\
\text { environment }\end{array}$ & 0.3 & 1.8 & 10.6 & 41.2 & 46.1 \\
\hline 19 & $\begin{array}{l}\text { Students increase their ability to develop a more } \\
\text { complicated system of environmental values }\end{array}$ & 0.3 & 0.9 & 7.6 & 40.9 & 50.3 \\
\hline 20 & $\begin{array}{l}\text { Students developed feelings of self-responsibility towards } \\
\text { the society where they are expected to live in }\end{array}$ & 0.3 & 1.8 & 15.2 & 43.8 & 38.9 \\
\hline 21 & $\begin{array}{l}\text { Students express willingness to get involved in actions } \\
\text { regarding the protection of the environment }\end{array}$ & 0.3 & 1.5 & 7.3 & 40.6 & 50.3 \\
\hline 22 & Students developed creativity and critical thinking & 1.2 & 1.2 & 11.2 & 51.2 & 35.2 \\
\hline 23 & Students displayed a strong interest in research & 1.2 & 1.5 & 14.5 & 43.9 & 38.8 \\
\hline 24 & $\begin{array}{l}\text { Students developed shared responsibility and effective } \\
\text { cooperation during group work }\end{array}$ & 0.3 & 0.9 & 5.2 & 27.7 & 66 \\
\hline 25 & Students displayed motivation and enthusiasm & 0.3 & 1.2 & 10.3 & 43.2 & 45 \\
\hline 26 & $\begin{array}{l}\text { Students developed their ability to describe in a more } \\
\text { precise way deeper feelings and thoughts }\end{array}$ & 0.3 & 0.3 & 7.6 & 37 & 54.8 \\
\hline \multicolumn{7}{|c|}{$\begin{array}{l}\text { When I assess my professional performance during the implementation of drama-based activities in Environmental Education, } \\
\text { I feel that: }\end{array}$} \\
\hline 27 & $\begin{array}{l}\text { I am well-trained and sufficient to use drama-based } \\
\text { activities in the context of the Environmental Education } \\
\text { Programs }\end{array}$ & 10.3 & 28.8 & 35.2 & 18.5 & 7.3 \\
\hline 28 & $\begin{array}{l}\text { My familiarization with the implementation of } \\
\text { Environmental Education Programs helps me experiment } \\
\text { with alternative educational methods }\end{array}$ & 3.3 & 15.8 & 29.4 & 33 & 18.5 \\
\hline
\end{tabular}


Table 2. Cont.

\begin{tabular}{|c|c|c|c|c|c|c|}
\hline \multirow[t]{2}{*}{ Variables } & & $\begin{array}{l}\text { Totally } \\
\text { Disagree }\end{array}$ & $\begin{array}{l}\text { Slightly } \\
\text { Disagree }\end{array}$ & $\begin{array}{l}\text { Neither } \\
\text { Disagree } \\
\text { nor Agree }\end{array}$ & $\begin{array}{l}\text { Slightly } \\
\text { Agree }\end{array}$ & $\begin{array}{l}\text { Totally } \\
\text { Agree }\end{array}$ \\
\hline & & $(\%)$ & $(\%)$ & $(\%)$ & $(\%)$ & $(\%)$ \\
\hline \multicolumn{7}{|c|}{$\begin{array}{l}\text { When I assess my professional performance during the implementation of drama-based activities in Environmental Education, } \\
\text { I feel that: }\end{array}$} \\
\hline 29 & $\begin{array}{l}\text { I prefer to use drama-based activities in the context of the } \\
\text { implementation of Environmental Education Programs } \\
\text { with the help of colleagues }\end{array}$ & 1.5 & 10.9 & 30.4 & 38 & 19.1 \\
\hline 30 & $\begin{array}{l}\text { The use of drama-based activities can facilitate the } \\
\text { implementation of Environmental Education Programs }\end{array}$ & 0.6 & 2.1 & 15.5 & 44.2 & 37.6 \\
\hline 31 & $\begin{array}{l}\text { The official Curricula should be reorganized to include } \\
\text { more time for drama-based activities in the classroom }\end{array}$ & 0.6 & 3.9 & 23.3 & 26.4 & 45.8 \\
\hline 32 & $\begin{array}{l}\text { The evaluation of the effectiveness of the use of } \\
\text { drama-based activities in the Environmental Education } \\
\text { Programs provides teachers with useful feedback and leads } \\
\text { to improvement of methods }\end{array}$ & 1.5 & 2.7 & 23.9 & 43.3 & 28.5 \\
\hline 33 & $\begin{array}{l}\text { Students themselves should also evaluate the effectiveness } \\
\text { of the use of drama-based activities on the Environmental } \\
\text { Education Programs }\end{array}$ & 0.9 & 5.5 & 20.6 & 46.7 & 26.4 \\
\hline
\end{tabular}

\subsection{Factor Analysis}

Based on the Principal Component (Rotation Method: varimax), the 33 variables were grouped into four factors. These four factors were as follows:

Factor 1: cognitive domain development: Variables (1), (2), (3), (4), (5), (6).

Factor 2: socio-affective domain development: Variables (7), (8), (9), (10), (11), (12), (13), (14), (15).

Factor 3: impact of drama-based activities during Environmental Education: Variables (16), (17), (18), (19), (20), (21), (22), (23), (24), (25), (26).

Factor 4: self-assessment regarding the implementation of drama-based activities in Environmental Education: Variables (27), (28), (29), (30), (31), (32), (33).

The results of the analysis of first two factors are given in the Table 3 below. The first factor accounts for $32.9 \%$ of the volatility, and the second for $29.2 \%$. In total, the two factors with eigenvalue $>1$ account for $62.1 \%$ of the variability. Loads ranged from 0.42 to 0.85 .

Table 3. Factor analysis of the cognitive and socio-affective domain development.

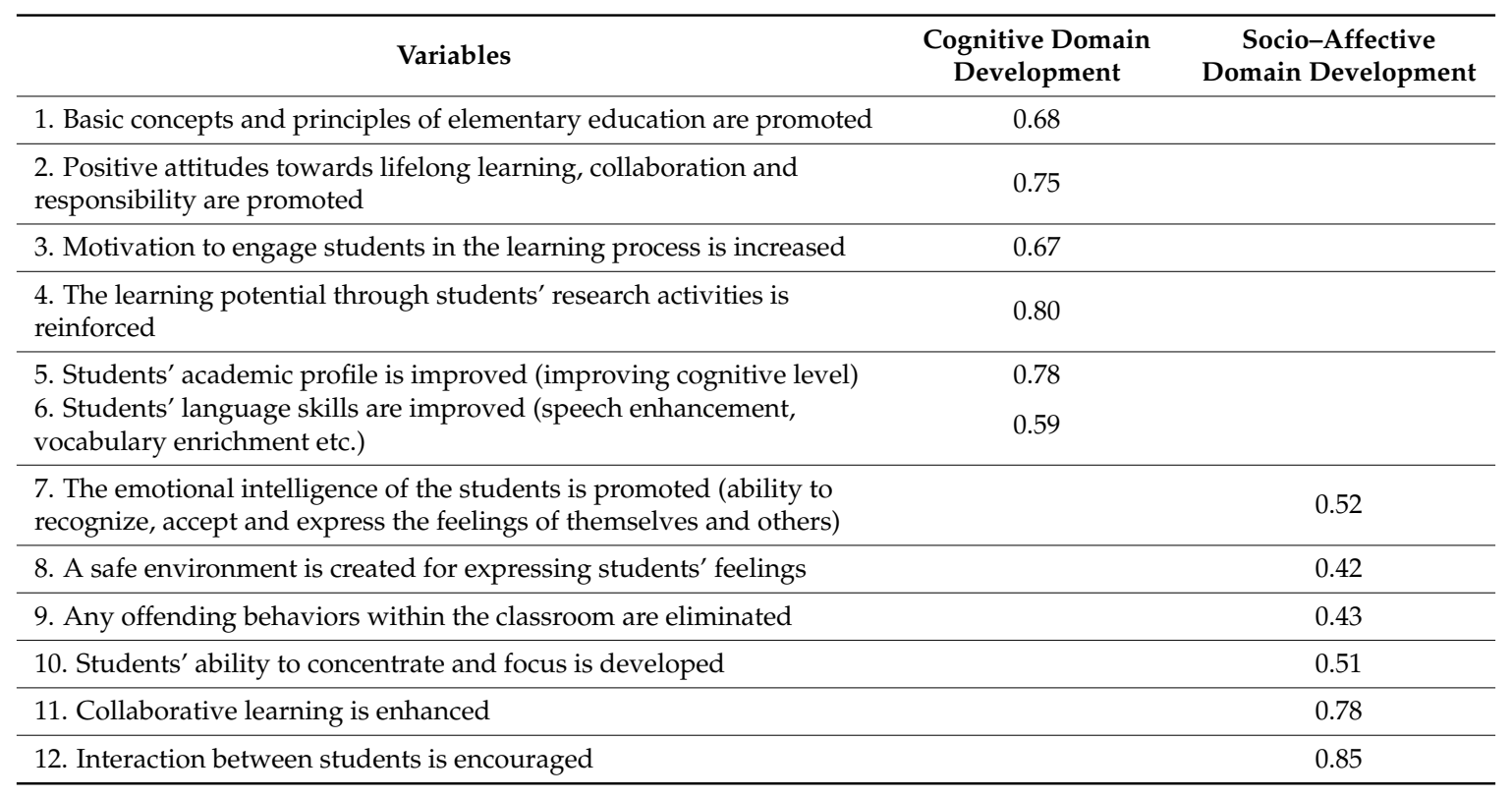


Table 3. Cont.

\begin{tabular}{lcc}
\hline \multicolumn{1}{c}{ Variables } & $\begin{array}{c}\text { Cognitive Domain } \\
\text { Development }\end{array}$ & $\begin{array}{c}\text { Socio-Affective } \\
\text { Domain Development }\end{array}$ \\
\hline 13. Interaction between students and teachers is increased & 0.83 \\
\hline 14. Acceptance of diversity among students is increased & 0.71 \\
\hline $\begin{array}{l}\text { 15. Enhanced empathy of students (The ability to recognize the needs of } \\
\text { others and to accept each other as they are) }\end{array}$ & 0.69 \\
\hline \% of the volatility explained: & 32.9 & 29.2 \\
\hline
\end{tabular}

The results of the analysis of the third factor are given in the Table 4 below. The factor explains $57.8 \%$ of the volatility. Loads ranged from 0.71 to 0.82 .

Table 4. Factor analysis of the impact of drama-based activities during Environmental Education.

\begin{tabular}{lc}
\hline \multicolumn{1}{c}{ Variables } & $\begin{array}{l}\text { Impact of Drama-Based Activities } \\
\text { during Environmental Education }\end{array}$ \\
\hline $\begin{array}{l}\text { 1. Students develop a deeper understanding of environmental issues } \\
\text { 2. Students develop an ability to successfully cope with contemporary } \\
\text { problems regarding the environment }\end{array}$ & 0.71 \\
\hline $\begin{array}{l}\text { 3. Students gain vivid experiences and feelings about the environment } \\
\text { 4. Students increase their ability to develop a more complicated }\end{array}$ & 0.73 \\
\hline system of environmental values & 0.76 \\
\hline $\begin{array}{l}\text { 5. Students developed feelings of self-responsibility towards the } \\
\text { society where they are expected to live in }\end{array}$ & 0.79 \\
\hline $\begin{array}{l}\text { 6. Students express willingness to get involved in actions regarding } \\
\text { the protection of the environment }\end{array}$ & 0.75 \\
\hline 7. Students developed creativity and critical thinking & 0.82 \\
\hline $\begin{array}{l}\text { 8. Students displayed a strong interest in research } \\
\text { 9. Students developed shared responsibility and effective cooperation } \\
\text { during group work }\end{array}$ & 0.77 \\
\hline $\begin{array}{l}\text { 10. Students displayed motivation and enthusiasm } \\
\text { 11. Students developed an ability to describe in a more precise way } \\
\text { deeper feelings and thoughts }\end{array}$ & 0.77 \\
\hline \begin{tabular}{l} 
\% of the volatility explained: \\
\hline
\end{tabular} & 0.78 \\
\hline
\end{tabular}

The results of the analysis of the fourth factor are given in the Table 5 below. The factor explains $40.2 \%$ of the volatility. Loads ranged from 0.55 to 0.75 .

Table 5. Factor analysis of the self-assessment regarding the implementation of drama-based activities in Environmental Education.

\section{Variables}

Self-Assessment Regarding the Implementation of Drama-Based Activities in Environmental Education

1. I am well-trained and qualified to use drama-based activities in the context of the Environmental Education Programs

2. My familiarization with the implementation of Environmental Education Programs helps me experiment with alternative educational methods

3. I prefer to use drama-based activities in the context of the implementation of Environmental Education Programs with the help of colleagues
0.57 
Table 5. Cont.

\begin{tabular}{lc}
\hline \multicolumn{1}{c}{ Variables } & $\begin{array}{c}\text { Self-Assessment Regarding the } \\
\text { Implementation of Drama-Based } \\
\text { Activities in Environmental Education }\end{array}$ \\
\hline $\begin{array}{l}\text { 4. The use of drama-based activities can facilitate the } \\
\text { implementation of Environmental Education Programs }\end{array}$ & 0.75 \\
\hline $\begin{array}{l}\text { 5. The official Curricula should be reorganized to include more } \\
\text { time for drama-based activities in the classroom }\end{array}$ & 0.64 \\
\hline $\begin{array}{l}\text { 6. The evaluation of the effectiveness of the use of } \\
\text { drama-based activities on the Environmental Education }\end{array}$ & 0.67 \\
$\begin{array}{l}\text { Programs provides teachers with useful feedback and leads to } \\
\text { improvements of methods }\end{array}$ & 0.64 \\
\hline $\begin{array}{l}\text { 7. Students themselves should also evaluate the effectiveness } \\
\text { of the use of drama-based activities on the Environmental }\end{array}$ & 40.2 \\
\hline Education Programs & \\
\hline \% of the volatility explained:
\end{tabular}

\subsection{Comments on the Factor Analysis Results}

The four main factors pinpointed by the factor analysis were as follows:

Factor 1: cognitive domain development. According to the results, the cognitive domain of teaching, which is enhanced through the use of drama-based activities, was linked to the strengthening of the students' academic profile, the reinforcement of the learning potential through students' research activities, the promotion of positive attitudes towards lifelong learning, collaboration, and responsibility. It was also linked to the promotion of basic concepts and principles of elementary education, and to the improvement of students' language skills and academic profile.

Factor 2: socio-affective domain development. According to the results, the affective domain of teaching seemed to be boosted by the use of drama-based activities in the classroom. Teachers linked it to the interaction developed between students and between students and teachers, the reinforcement of collaborative learning, empathy, and acceptance of diversity. They also associated it with the development of emotional intelligence in the students, the enhancement of students' ability to concentrate and focus, the creation of a safe environment for expressing students' feelings, and finally the elimination of offending behaviors within the classroom.

Factor 3: impact of drama-based activities during Environmental Education. According to the results, teachers seemed to believe that students who participate in drama-based activities during Environmental Education are more likely to develop a deeper understanding of, and sensitivity towards environmental issues, and worked to protect the environment in more active and effective ways. At the same time, teachers seemed to believe that these students could develop critical thinking and become more resourceful, cooperative, enthusiastic, and extroverts during their participation in drama-based activities. These findings have been also confirmed by relevant research conducted in Greek primary schools [38,39].

Factor 4: self-assessment regarding the implementation of drama-based activities in Environmental Education. According to the results, teachers strongly believed that the use of drama-based activities can facilitate the implementation of Environmental Education programs, and that the effectiveness of the use of drama-based activities on Environmental Education programs should be evaluated by the Environmental Education Directors, and by the students themselves. Moreover, teachers reported that, the official Curricula should be reorganized to include more time for drama-based activities in the classroom. Teachers also believed that their familiarization with the implementation of Environmental Education Programs helped them experiment with alternative educational methods, but they preferred the use of drama-based activities with the help of colleagues because not many 
of them feel well-trained and sufficiently qualified to use drama-based activities in the context of the Environmental Education Programs.

\subsection{Greek Teachers' Self-assessment Regarding Drama-Based Activities}

Table 6 gives the ratings for the teachers' self-assessment regarding the use of drama-based activities in the Environmental Education, depending on participants' gender, age, education, training, instructional methods, and collaborative work with other teachers.

Table 6. Ratings for the teachers' self-assessment.

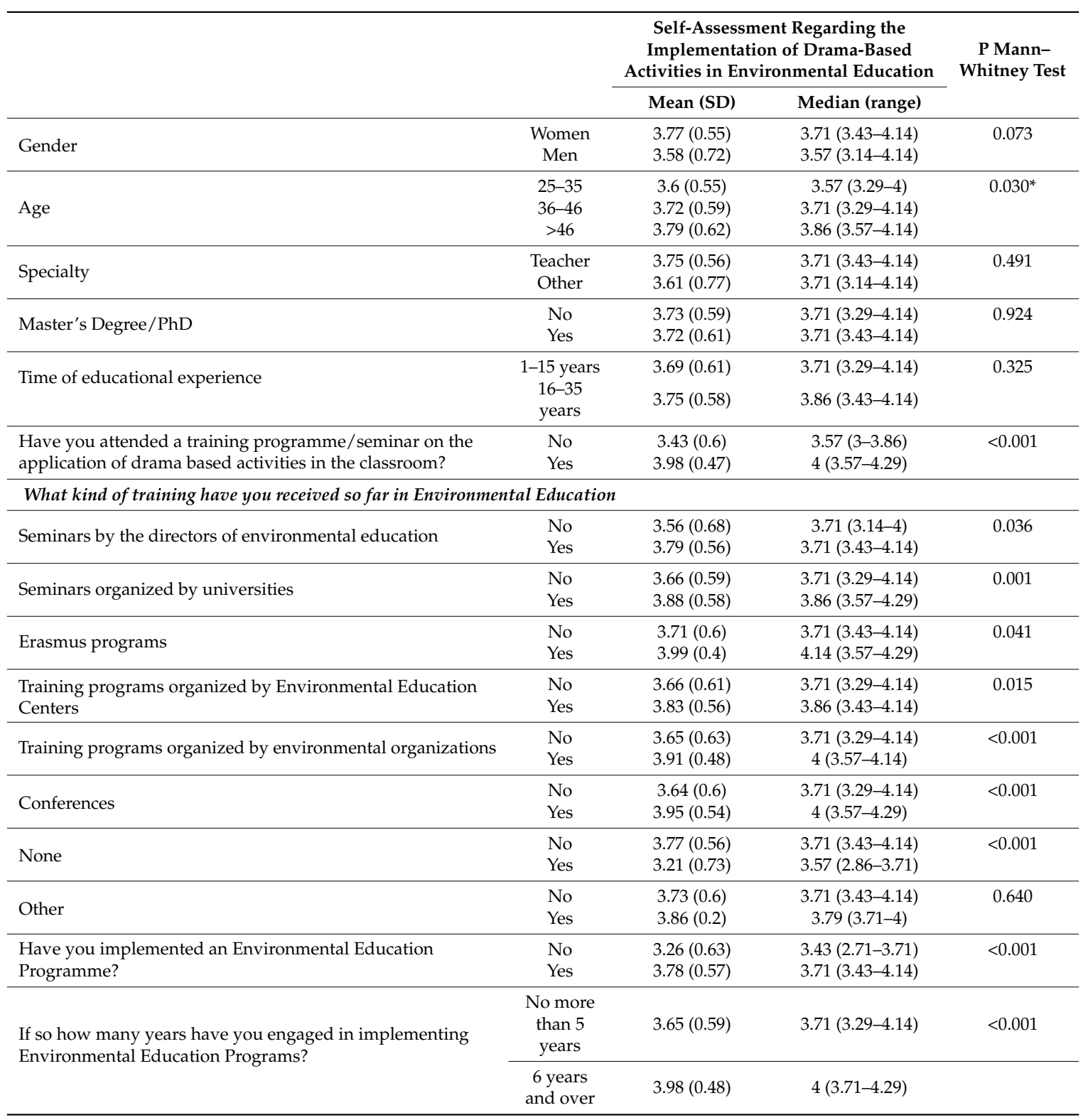


Table 6. Cont.

\begin{tabular}{|c|c|c|c|c|}
\hline & & \multicolumn{2}{|c|}{$\begin{array}{l}\text { Self-Assessment Regarding the } \\
\text { Implementation of Drama-Based } \\
\text { Activities in Environmental Education }\end{array}$} & \multirow[t]{2}{*}{$\begin{array}{l}\text { P Mann- } \\
\text { Whitney Test }\end{array}$} \\
\hline & & Mean (SD) & Median (range) & \\
\hline \multicolumn{5}{|c|}{ Which teaching method do you usually use to teach environmental issues } \\
\hline \multirow{2}{*}{ Environmental excursions } & No & $3.69(0.62)$ & $3.71(3.43-4.14)$ & 0.402 \\
\hline & Yes & $3.75(0.59)$ & $3.71(3.43-4.14)$ & \\
\hline Use of new technologies & Yes & $3.75(0.54)$ & $3.71(3.43-4.14)$ & \\
\hline \multirow{2}{*}{ Use of drama based activities (improvisation, role playing etc.) } & No & $3.5(0.6)$ & $3.57(3.14-4)$ & $<0.001$ \\
\hline & Yes & $4(0.46)$ & $4(3.71-4.29)$ & \\
\hline \multirow{2}{*}{ Projects } & No & $3.65(0.62)$ & $3.57(3.14-4.14)$ & 0.134 \\
\hline & Yes & $3.76(0.58)$ & $3.71(3.43-4.14)$ & \\
\hline Free dialogue in the classroom & Yes & $3.71(0.65)$ & $3.71(3.43-4.14)$ & \\
\hline \multirow{2}{*}{ Other } & No & $3.73(0.6)$ & $3.71(3.43-4.14)$ & 0.510 \\
\hline & Yes & $3.89(0.59)$ & $3.71(3.71-4.29)$ & \\
\hline \multirow{2}{*}{$\begin{array}{l}\text { Have you worked with colleagues from other classes or } \\
\text { specialties to implement Environmental Education Programs }\end{array}$} & No & $3.43(0.58)$ & $3.43(3-3.71)$ & $<0.001$ \\
\hline & Yes & $3.81(0.57)$ & $3.86(3.57-4.14)$ & \\
\hline \multicolumn{5}{|c|}{ Which colleagues have you worked with to implement environmental education programs? } \\
\hline \multirow{2}{*}{ Teacher from other class } & No & $3.59(0.6)$ & $3.57(3.29-4)$ & 0.001 \\
\hline & Yes & $3.8(0.58)$ & $3.86(3.57-4.14)$ & \\
\hline \multirow{2}{*}{ Teacher of physical education } & No & $3.66(0.63)$ & $3.71(3.29-4.14)$ & $<0.001$ \\
\hline & Yes & $3.95(0.4)$ & $4(3.71-4.29)$ & \\
\hline Teacher of new technologies & Yes & $3.9(0.49)$ & $4(3.71-4.29)$ & \\
\hline \multirow{2}{*}{ Teacher of foreign languages } & No & $3.7(0.6)$ & $3.71(3.43-4.14)$ & 0.010 \\
\hline & Yes & $3.91(0.53)$ & $4(3.71-4.29)$ & \\
\hline \multirow{3}{*}{$\begin{array}{l}\text { Do you use drama-based activities in the context of } \\
\text { implementing environmental education programs in the } \\
\text { classroom? }\end{array}$} & $\begin{array}{l}\text { Not at } \\
\text { all/Slightly }\end{array}$ & $3.42(0.57)$ & $3.43(3.14-3.71)$ & $<0.001^{*}$ \\
\hline & Enough & $3.86(0.52)$ & $3.86(3.57-4.14)$ & \\
\hline & $\begin{array}{l}\text { Much/Very } \\
\text { much }\end{array}$ & $4.22(0.38)$ & $4.29(4-4.43)$ & \\
\hline
\end{tabular}

The results of Table 6 show that as the age of the participants increases, the more positively they assessed the application of drama-based activities to Environmental Education.

A significantly more positive assessment of the application of drama-based activities in the Environmental Education was from those participants who had attended a training program/seminar on the application of drama-based activities in the classroom.

Participants who had not received any training in Environmental Education had a significantly less positive assessment towards the use of drama-based activities in Environmental Education than those who had had already received training.

In particular, participants attending seminars provided by Environmental Education Directors and during university education programs, mobility programs, curriculum development programs, conferences, and in Environmental Education Centers, tended to be more positive towards drama-based activities in comparison to those who had not attended such seminars.

A significantly more positive assessment of the implementation of drama-based activities in Environmental Education was from those participants who had implemented at least one 
Environmental Education Program in the classroom and those who had been involved in the implementation of such programs for at least six years.

The positive assessment towards the use of drama-based activities in Environmental Education depends was also on the instructional methods participants use to teach environmental issues. Results showed that those who used less conventional methods, such as drama-based activities, working with groups and free dialogue within the classroom, were more positive about using drama-based activities in Environmental Education.

A significantly more positive attitude towards the use drama-based activities in Environmental Education was from participants who collaborated with their colleagues (and specifically teachers from other classes and drama teachers) for the implementation of Environmental Education programs.

\section{Discussion and Conclusions}

The present study examined Greek primary school teachers' perceptions about the use of drama-based activities as a means of enhancing, supporting, and developing Environmental Education objectives. According to the results, teachers have a positive attitude towards the use of drama-based activities in the educational process in general, and in Environmental Education in particular.

On the one hand, the cognitive domain of teaching, which is enhanced through the use of drama-based activities, as Factor 1 implies, is linked to the improvement of the learning potential through students' research activities. This agrees with the survey by Alaba and Tayo [40], who reported that students' attitude and knowledge were enhanced when using drama because of its participatory, motivating, creative, and activity-based characteristics as a teaching method. Moreover, teachers report that positive attitudes towards lifelong learning are developed along with collaboration and responsibility. Basic concepts and principles of elementary education were promoted and-similarly to what McGregor [41] reports—students' language skills and academic profile were improved, providing students with many more opportunities to develop their curiosity, "open" thinking and interactive skills.

Greek teachers also believe that the affective domain of teaching seems to be boosted by the use of drama-based activities in the classroom, as Factor 2 implies, and link it to the interaction made between students and between students and teachers, the reinforcement of collaborative learning and empathy as Littledyke $[35,36]$ reports. The acceptance of diversity and the promotion of emotional intelligence in students are also developed [13]. The enhancement of students' ability to concentrate and focus is achieved as reported by Curtis and colleagues [27], a finding that points out students' focus and commitment to knowledge. Finally, according to the present research, the creation of a safe environment for expressing students' feelings and the elimination of offending behaviors within the classroom are promoted, confirming thus the findings by Sakovelis, Papasotiropoulou, and Vlachos [42].

Other findings of our research show that Greek teachers relate the use of drama-based activities with the enhancement of Environmental Education's multi-layered objectives (Factor 3): one of these is students' familiarization with creative learning strategies and critical interpretation of real environmental data, which confirms the findings of Clark and Button's survey [34].

In addition, teachers seem to believe that through the use of drama-based activities in the classroom, students' preparation of being tomorrow's active citizens is enhanced, as well as their initiatives at action level, confirming what McNaughton reported [13]. Moreover, teachers believe that the students' research interest and their skills in identifying and solving modern environmental problems are boosted $[27,32]$. Finally, teachers report that strengthening team work and empirical experiential learning [13], raising awareness about environmental issues [33], shaping values and awareness towards the environment [14], enhancing students' interest in actively participating in environmental protection actions [35,36], and students' ability to express ideas and opinions, are also linked to the use of drama-based activities in Environmental Education.

The findings of the research pointed out also three key preconditions that are essential for shaping positive attitudes in teachers towards the use of drama-based activities in the Environmental Education. The first is teacher training or lack of training regarding the use of drama-based activities 
in the Environmental Education. The appropriate drama education and training along with the right organization for their teaching is crucial as Pantidos, Spathi, and Vitoratos, report [43]. Participants who had a tendency to participate in continuous training had a positive attitude towards this particular teaching method. Teachers who had used drama-based activities in the classroom systematically, could see their contribution to students' personality development as regards sensitivity, determination, commitment, and knowledge about environmental issues. The more the benefits for their students, the higher their positive attitude towards the use of drama-based activities. The second aspect that seems to be related to the use of drama-based activities by the participants is the opportunities provided by the official Curricula for collaborative work with other teachers on environmental issues. Teachers seem to be more confident when collaborating with their colleagues on teaching environmental issues. Because of their high sense of responsibility towards their students, the majority of the participants prefer to collaborate with professionals such as drama teachers, because of their expertise. This finding corresponds to the results of Gale [25], who report the importance of implementing drama-based activities by specialist trainers-such as drama teachers-with a clear separation of roles by each involved person, a specific action plan drawn up by the instructor and particular attention to the fact that the theatrical part does not exceed the didactic-environmental. Thus, a need for every Greek elementary school to have a drama teacher emerged, and also the need for including drama teachers as trainers in the teacher training seminars and programs. Finally, the third aspect which is linked to the positive attitude towards the use of drama-based activities in Environmental Education is the use of alternative teaching methods in the classroom. Participants who tended to try teaching methods in the classroom that go beyond traditional teaching such as drama, team work, projects, and free dialogue in the classroom, are very keen on using drama -based activities.

On the other hand, the results reveal some difficulties in the implementation of this particular teaching method. One key issue is the sense of inadequacy experienced by teachers due to inadequate training in using drama-based activities. It seems to be in fact a paradox that teachers evaluate relevant activities as quite important and at the same time they report that they feel inadequately prepared to use them in their classroom. This paradox could possibly be explained if one takes into account that undergraduate student teachers have been provided with extensive theoretical information about the importance of alternative teaching methods, including drama-based activities. However, they lack opportunities for extensive undergraduate training on their effective use in real classroom settings. As a result, when they become active teachers they have theoretical knowledge but not practical experience; while restrictions related to the inflexibilities of the official Curricula do not give teachers a free hand in the use of such methods in the classroom.

This is in line with research findings of Metinnam, Keleşoğlu, and Özen [44] who reported that even teachers that took creative drama as a compulsory lesson at university, experience a lot of confusion in concepts relating to the field. Duban and Düzgün [7] also report that teacher training should include practical activities for the use of drama.

Another obstacle according to our results is the time pressure teachers experience because of the official Curricula, which probably explains why the majority of the participants believe that the timetable must be reorganized to include more time for drama-based activities in the classroom. That confirms the research findings of Metinnam, Keleşoğlu, and Özen [44], who suggest an increase in the weekly lesson hours of the Civics lesson included in the curriculum, and also Bång's survey [45], where it was shown that the two concerns brought up by the teachers were their lack of knowledge in drama and lack of time in the Curricula. It should also be stated that in Greek Curricula it is not directly written how much time should be devoted to a particular teaching method. Thus, partially the decision about which method a teacher should use, as well as about the pace of teaching, depends on his/her personality, and, for this reason, teachers are prompted to choose teaching methods in which they feel confident.

The present study had some limitations. The participants were teachers only from the prefecture of Attica and only from Primary schools. In future studies, the sample could be extended to other 
Greek regions, as well as to all levels of the Greek educational system (Middle and Higher Education), in order to have a more holistic approach. Nevertheless, as drama is not a remedy for "all the evil" in education, more work and research for the matter is needed.

Despite the restrictions, this study has shown that Greek primary school teachers are willing to use alternative educational methods in the classroom, such as drama-based activities, despite the obstacles and limitations presented by the official curricula. These findings confirm the need for improvements, which should be made in order to facilitate teachers' efforts regarding the implementation of drama-based activities in the classroom. Papadopoulos reports that theatre play and dramatization are basic methods of theatre education in contemporary Greek school [46]. It is therefore necessary to familiarize teachers with these methods, both on the theoretical and experiential level. The training offers the opportunity to raise awareness and acquire the relevant experience in the new data of theatrical research [47]. Drama lessons should be taught at all levels of Greek official education, and not only in primary schools, in order for students to become familiar with drama activities and be ready to respond to this alternative educational method. Furthermore, drama lessons in schools and teacher trainings, should be carried out only by specialists such as drama teachers. Finally, there should be a change in the official curricula timetable, so that teachers who wish to implement drama-based activities in the classroom do not feel hindered by the timetable.

The present research has shown that Greek teachers, like their counterparts worldwide, are willing to implement inspiring alternative teaching strategies, such as drama-based activities, in their classrooms, and use them to serve and disseminate humanistic and environmental values of great importance, on the condition that specialized knowledge, official support, and freedom are also provided. Finally, this research has also confirmed that teachers worldwide can accomplish highly-ranked teaching objectives [48] when they are sufficiently trained, professionally encouraged and institutionally supported-a challenge so common and, at the same time, so difficult for all educational systems around the world.

Author Contributions: Conceptualization, E.A. and K.K.; methodology, E.A. and K.K.; software, E.A.; validation, E.A. and K.K.; investigation, E.A.; data curation, E.A. and K.K.; writing-original draft preparation, E.A.; writing - review and editing, K.K.; visualization, E.A. and K.K.; supervision, K.K.

Funding: This research received no external funding.

Acknowledgments: The authors acknowledge the valuable comments of the anonymous reviewers which contributed to the improvement of the quality and acceptability of the paper.

Conflicts of Interest: The authors declare no conflict of interest.

\section{References}

1. Dervishaj, A. Using Drama as a Creative Method for Foreign Language Acquisition. Linguist. Commun. Perform. J. 2009, 2, 53-62.

2. Kempe, A. Daisy's Diary: Issues Surrounding Teaching History through Drama. Drama Res. 2011, 2, 2.

3. Küppers, A. Cultural learning through drama tasks: An action research approach. Scenario 2012, 6, 1-7.

4. Tsiaras, A. Teaching Poetry through Dramatic Play in Greek Primary School: Surveying Teachers' and Pupils' Views. N. Z. J. Res. Perform. Arts Educ. Nga Mahi A Rehia No Aotearoa 2016, 6, 38-48.

5. Thomas, E.; Mulvey, A. Using the arts in teaching and learning: Building student capacity for community-based work in health psychology. J. Health Psychol. 2008, 13, 239-250. [CrossRef] [PubMed]

6. Andersen, C. Learning in "As-If" Worlds: Cognition in Drama in Education. Theory Pract. 2004, 43, 281-286. [CrossRef]

7. Duban, N.Y.; Düzgün, M.E. Views of teachers on the use of drama method in science and technology courses. Turk. Online J. Qual. Inq. 2013, 4, 46-55.

8. Morgan, K.; Jones Robyn, L.; Gilbourne, D.; Llewellyn, D. Changing the face of coach education: Using ethno-drama to depict lived realities. Phys. Educ. Sport Pedagog. 2013, 18, 520-533. [CrossRef]

9. Flintoff, K. Drama and Technology: Teacher Attitudes and Perceptions. 2005. Available online: http:/ / ro.ecu.edu.au/theses/565 (accessed on 22 January 2019). 
10. Freire, P. The Pedagogy of the Oppressed; The Seabury Press: New York, NY, USA, 1970.

11. Hooks, B. Teaching to Transgress: Education as the Practice of Freedom; Routledge: New York, NY, USA, 1994.

12. De los Reyes, E.; Gozemba, P. Pockets of Hope: How Students and Teachers Change the World; Bergin \& Garvey: Westport, CT, USA, 2002.

13. McNaughton, M. Learning from participants' responses in educational drama in the teaching of Education for Sustainable Development. Res. Drama Educ. J. Appl. Theatre Perform. 2006, 11, 19-41. [CrossRef]

14. Çokadar, H.; Yilmaz, G. Teaching Ecosystems and Matter Cycles with Creative Drama Activities. J. Sci. Educ. Technol. 2010, 19, 80-89. [CrossRef]

15. Warren, K. Empowering children through drama. Early Child Dev. Care 2003, 90, 83-97. [CrossRef]

16. Neelands, J. Making Sense of Drama: A Guide to Classroom Practice; Heinemann Educational Books \& 2D Magazine: London, UK; Portsmouth, NH, USA, 1984.

17. Kontoyianni, A. Black Cow—White Cow: Drama in Education and Interculturality; Topos: Athens, Greece, 2008. (In Greek)

18. Hanratty, B. Opening the windows of wonder: A critical investigation into the teaching and learning of poetry at Key Stage Four in Northern Ireland. Ir. Educ. Stud. 2007, 27, 147-158. [CrossRef]

19. Tsiaras, A. Dramatic play as a means of teaching poetry in primary education. In Proceedings of the 7th International Conference on Theater in Education-Solidarity Links, Hellenic Network for Theater in Education, Athens, Greece, 23 November 2012; pp. 328-334.

20. McCullough, C.N. The Impact of Socio-Dramatic Play upon the Language Development of Language-Delayed Primary-Aged Children. Unpublished. Ph.D. Thesis, State University of New York, Buffalo, NY, USA, 2000.

21. Ciussi, M.; Gebers Freitas, E. Leading Issues In E-Learning Research: For Researchers, Teachers and Students; Academic Publishing International: Reading, UK, 2012.

22. Fien, J.; Tilbury, D. The Global Challenge of Sustainability. In Education and Sustainability: Responding to the Global Challenge; Tilbury, D., Stevenson, R., Fien, J., Schreuder, D., Eds.; IUCN: Cambridge, UK, 2002.

23. Perdikari, S.; Skanavis, C.; Kontoyianni, A. Research and study of the "Environmental Characteristics" of Pre-school Education Teachers. Mod. Educ. 2005, 141, 156-175. (In Greek)

24. Barr, S. Are we all environmentalists now? Rhetoric and reality in environmental action. Geoforum 2004, 35, 231-249. [CrossRef]

25. Gale, H. How does drama work in environmental education? Earth Environ. 2008, 3, 159-178.

26. Kagan, S.; Kirchberg, V. (Eds.) Sustainability: A New Frontier for the Arts and Cultures; Verlag für Akademische Schriften: Waldkirchen, Germany, 2008.

27. Curtis, J.D.; Howden, M.; Curtis, F.; McColm, I.; Scrine, J.; Blomfield, T.; Reeve, I.; Ryan, T. Drama and Environment: Joining Forces to Engage Children and Young People in Environmental Education. Aust. J. Environ. Educ. 2013, 29, 182-201. [CrossRef]

28. Ramsey, D. The role of music in environmental education: Lessons from the cod fishery crisis and the dust bowl days. Can. J. Environ. Educ. 2002, 7, 1-16.

29. Hoot, J.L.; Foster, M.L. Promoting ecological responsibility ... through the arts. Child. Educ. 1993, 69, 150-155. [CrossRef]

30. Appleby, E. Mrs Blue Gum, some puppets and a remnant forest: Towards sustainability education through drama pedagogy. Aust. J. Environ. Educ. 2005, 21, 1-10. [CrossRef]

31. Wilson, R.; Harmon, M. Young naturalist center. In Environmental Education at the Early Childhood Level; Wilson, R., Ed.; North American Association for Environmental Education: Troy, NY, USA, 1994; pp. 92-97.

32. Choi, Y. Literature and environmental affairs: Ibsen's “An enemy of the people". J. Environ. Educ. 1983, 14, 37-40. [CrossRef]

33. Bailey, S.; Watson, R. Establishing basic ecological understanding in younger pupils: A pilot evaluation of a strategy based on drama/role play. Int. J. Sci. Educ. 1998, 20, 139-152. [CrossRef]

34. Clark, B. Sustainability transdisciplinary education model: Interface of arts, science, and community (STEM). Int. J. Sustain. High. Educ. 2011, 12, 41-54. [CrossRef]

35. Littledyke, M. Drama and primary science. In Proceedings of the Annual Meeting of British Educational Research, Leeds, UK, 13-15 September 2001; Volume 143. Available online: http:/ /brs.leeds.ac.uk/cgi-bin/ brs_engine (accessed on 22 January 2019). 
36. Littledyke, M. Converging paradigms: Bridging Science and Environmental Education through Drama. In International Perspectives in Environmental Education; Filho, W., Littledyke, M., Eds.; Peter Lang International: Berlin, Germany, 2004; pp. 37-56.

37. OECD. Creating Effective Teaching and Learning Environments: First Results from TALIS; OCED: Paris, France, 2009; p. 89, ISBN 978-92-64-05605-3. Available online: https://www.oecd.org/education/school/43023606. pdf (accessed on 22 January 2019).

38. Andrikopoulou, E.; Koutrouba, K. Improvised eco-Theatre as educational tool for the environmental awareness of elementary students. In Proceedings of the EDULEARN17 Conference, Barcelona, Spain, 3-5 July 2017; pp. 2818-2827.

39. Andrikopoulou, E.; Koutrouba, K. Greek primary school teachers' perceptions about using drama-based activities in the context of environmental education. In Proceedings of the ICERI17 Conference, Seville, Spain, 12-14 November 2018.

40. Alaba, S.O.; Tayo, O.K. A Study of the Effectiveness of Socio-Drama Learning Package in Promoting Environmental Knowledge and Behaviour of Secondary Schools Students in Osun State, Nigeria. Mediterr. J. Soc. Sci. Mcser Publ. 2014, 5. [CrossRef]

41. McGregor, D. Dramatising Science Learning: Findings from a pilot study to re-invigorate elementary science pedagogy for five- to seven-year olds. Int. J. Sci. Educ. 2012, 34, 1145-1165. [CrossRef]

42. Sakoveli, P.; Papasotiropoulou, K.; Vlachos, I. "One, two, three, the bell rings... Good morning Environment" Connecting the Environmental and Theater Education. In Inspiration, Reflection, Imagination in Environmental Education, Proceedings of the 2nd Hellenic Symposium, 1-3 April, 2005; Kalaitzidis, D., Ed.; University of Piraeus: Piraeus, Greece, 2005. (In Greek)

43. Pantidos, P.; Spathi, K.; Vitoratos, E. The teaching of physical sciences as theatrical performance. In Proceedings of the International Conference on History and Philosophy of Physics in Education, Bratislava, Slovakia, 21-24 August 1996; pp. 147-151.

44. Metinnam, İ.; Keleşoğlu, S.; Özen, Z. Teachers' Views on Using Creative Drama as a Method in Social Studies Education. J. Educ. Future 2014, 6, 43-57.

45. Bång, O. Drama as a Pedagogical Tool in Technology Education. A Study of Teachers' Perceptions of Drama Exercises When Teaching Ethics in Technology. 2017. Available online: http:/ / www.diva-portal.se/smash/ get/diva2:1103545/FULLTEXT01.pdf (accessed on 22 January 2019).

46. Papadopoulos, S. Theater education and teacher training. Theory and applications. In The Theater as Educational Good and Artistic Expression in Education and Society; Grammatas, T., Ed.; Act 'Thalis'-University of Athens: Athens, Greece, 2013; pp. 97-127. (In Greek)

47. Grammatas, T. (Ed.) Theater Education and Teacher Training; Athens: Typothito: Athens, Greece, 1997. (In Greek)

48. Brinia, V.; Athanasiou, A. Teachers' Views and Attitudes on the Organization and Implementation of the Social and Emotional Intelligence Education Program. Educ. Quart. Rev. 2018, 1, 47-65. 